\title{
Analysis of Multidrug Resistance Profile of Escherichia coli from Clinical Samples from Companion Animals and Bird Retrospect to Five-year (2015-2019) Literature Data
}

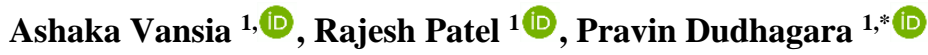 \\ 1 Department of Biosciences (UGC-SAP-II \& DST-FIST-I), Veer Narmad South Gujarat University, Surat, Gujarat, India \\ * Correspondence: pravindudhagara@vnsgu.ac.in;
}

Scopus Author ID 56082157200

Received: 16.12.2020; Revised: 18.01.2021; Accepted: 22.01.2021; Published: 30.01.2021

\begin{abstract}
Based on WHO 2017 data of death rate among the children of aging under five years, a diarrheal disease in post-neonates and sepsis in neonate posse second and third major concern, respectively. Though Group B Streptococci infection is a primary etiological agent, Escherichia coli infection is the major cause of mortality. Multidrug resistance in E. coli was studied from companion animals, addressing zoonotic disease transfer possibilities to their handler or in the community via direct or indirect contact or through contaminated food or water. Out of 100 samples cultured, 78 bacterial pathogens were isolated, from which $29(38 \%)$ isolates were E. coli, identified using IMViC and confirmed by Vitek2. Antibiotic susceptibility against 42 antibiotics belonging to 12 different antimicrobial categories was performed by the Kirby-Bauer method of disk diffusion assay. By using WHONET software, an antibiogram was deduced and found that $23(80 \%)$ isolates were multidrugresistant (MDR) and 4 (13\%) were possible extensively drug-resistant (possible XDR). Comparison of resistance data to the literature data of the period 2015-2019 supplemented with details of susceptibility either in the form of disc diffusion test or minimum inhibitory concentration (MIC) was carried out to understand the current scenario of drug resistance in E. coli of non-human origin.
\end{abstract}

Keywords: multidrug resistance; MDR; Escherichia coli; animal pathogen; zoonotic transfer; antimicrobial susceptibility.

(C) 2021 by the authors. This article is an open-access article distributed under the terms and conditions of the Creative Commons Attribution (CC BY) license (https://creativecommons.org/licenses/by/4.0/).

\section{Introduction}

Escherichia coli is an opportunistic pathogen reportedly accounting for approximately $8.8 \%$ of the total mortality rate in India [1] due to Multiple Drug Resistance (MDR) or Extensively Drug Resistance (XDR) urinary tract infections as well as E. coli associated diarrhea [2]. The presence of Extended Spectrum Beta-Lactamase positive or pathogenic MDR E. coli in samples from companion animals [3], milk of cows, pigs [4], poultry species [5,6], and even in the captive wildlife found in zoos and wildlife enclosures [2] was studied previously. Pathogens can transfer between human and their companion animals, birds, or livestock [7] even at their healthy state [8] is a known fact. One recent multi-country study was conducted to amputate antibiotics' usage and their corresponding resistance to E. coli. According to this study, the use of aminoglycosides, carbapenem, fluoroquinolones, and glycopeptide antibiotics are lower in India than in other countries. However, the percentage of resistance against them is higher. Even the study of a significant relationship between MDR or XDR E. coli infection and mortality rate in India found that as compared to non-MDR E. coli 
infections, the odds of mortality were 2.63 times higher for MDR E. coli, 2.23 times higher for ESBL positive E. coli, and 2.43 times higher for XDR E. coli (at 95\% Confidence Interval) [9]. According to the Veterinary Guideline (VET08), the Clinical and Laboratory Standard Institute, resistant or intermediate isolates may pose epidemiological threats to the particular region [10]. Hence, this study is designed to isolate E. coli and study their antibiotic sensitivity to categorize isolates to understand the current scenario in the locality as a part of one health approach.

\section{Materials and Methods}

A study design includes analyzing the pattern of antimicrobial resistance in Escherichia coli isolated from wounded or infectious companion animals and birds, including cattle and dogs in the South Gujarat region. No animals were killed or harmed during sampling. Samples were either procured from a microbiological laboratory or collected under a veterinarian's supervision from the clinic or in the stable by a trained laboratory technician. All the data obtained is solely for research purposes only. No treatment was deduced from the research to the animals.

Samples collected, including urine, feces, milk, tissue, a swab from infection site or wound, nasal cavity, or pus, were brought up in the icebox to the laboratory. Isolation of aerobic bacterial pathogens was performed within three hours as per standard procedures by streaking on Nutrient agar, MacConkey's agar, Blood agar, and Chocolate agar followed by incubation at $37^{\circ} \mathrm{C}$ for $24-48 \mathrm{~h}$.

Primary identification of all the isolates was carried out by standard microbial culturebased tests including morphological, colonial characteristics, IMViC test, and Sugar fermentation tests, followed by specialized tests - Haemolysis test Blood Agar (BA) and Eosin Methylene Blue (EMB) agar. Results of biochemical tests were subjected to an online taxonomic identification tool - "ABIS /REGNUM PROKARYOTAE" [11] to get probable isolate details, which were then confirmed by automated identification system VITEK 2. Escherichia coli NCIM 2645 and Escherichia coli NCIM 2065 strains were used as positive control while samples from infectious animals, yet giving no bacterial growth, serve as a negative control for samples.

The antimicrobial susceptibility of each isolate was carried out in Muller - Hinton (MH) Agar by Kirby-Bauer method of disk diffusion test [12]. Single disks of 42 different antibiotics (HiMedia) belonging to 12 different antimicrobial classes were tested following CLSI (Clinical Laboratory Standard Institute) Vet08 Guideline [10], and zone diameter in millimeter were noted down after incubation at $35^{\circ} \mathrm{C} \pm 2{ }^{\circ} \mathrm{C}$ for $16-18$ hours. A new manual library was prepared in the WHONET 2019 software [13], to which antimicrobial susceptibility data were feed to obtain the sensitivity results. Characterization of each isolates based on the susceptibility pattern into multidrug resistance (MDR) or extensively drug resistance (XDR) was done by following the definition given by Magiorakas et al. [14] and WHONET 2019 software.

For the literature analysis, research papers from PubMed were screened for 2015 to 2019, showing antimicrobial resistance analysis from domestic or wild animals or birds along with food sources to judge the current antimicrobial resistance scenario in E. coli. Inclusion criteria were the research paper supplemented with the susceptibility data either in the form of disk diffusion or minimum inhibitory concentration (MIC) to deduce the category of resistance phenotype by following the definition of Magiorakas et al. [14]. 


\section{Results and Discussion}

\subsection{Sampling, isolation, and identification of a pathogen.}

In the first stage of sampling, 100 bacterial isolates were obtained, both gram-negative and gram-positive bacteria, out of which $\mathrm{N}=35$ (46\%) isolates were gram-negative pathogens. (Figure 1) They were further categorized as Escherichia coli $(\mathrm{N}=29,38 \%)$ using microbial culture-based techniques as follows: positive catalase test, negative oxidase test, positive indole production, positive methyl red test, negative Voges-Proskauer test, negative citrate test (IMViC), positive hemolysis on blood agar and metallic sheath on EMB (Eosin Methylene Blue) agar with motile, gram-negative bacilli or cocci bacilli. These results, along with sugar fermentation tests, were subjected to an online taxonomic identification tool - ABIS/Regnum Prokaryotae [11] for probable isolate identification and confirmation of isolates were done by VITEK® 2 (BioMériux, USA). Other gram-negative isolates were Pseudomonas aeruginosa $(\mathrm{N}=2,3 \%)$, Acinetobacter sp. $(\mathrm{N}=1,1 \%)$, Enterobacter sp. $(\mathrm{N}=1,1 \%)$ and Klebsiella aerogenes $(\mathrm{N}=2,31 \%)$.

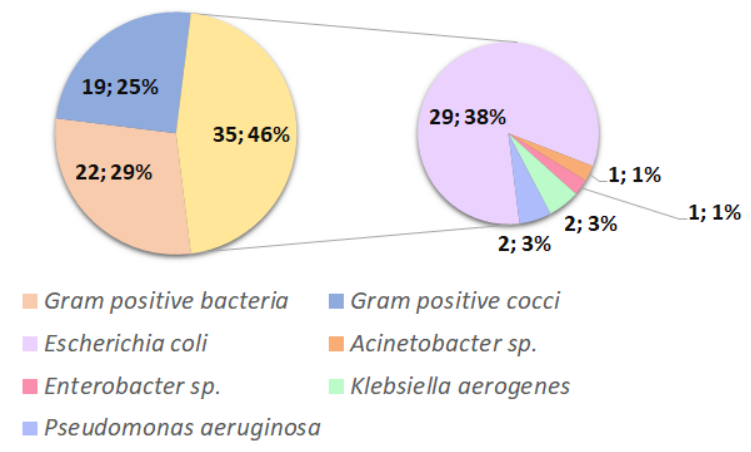

(a)

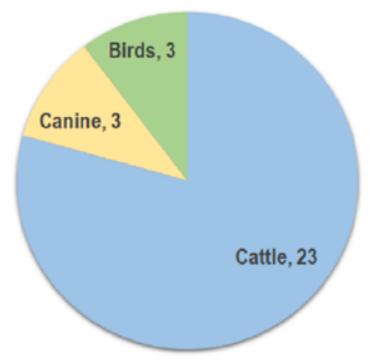

(b)

Figure 1. Isolate details: (a) Total percentage of isolates (samples, $\mathrm{N}=100$ ); (b) Number of Escherichia coli isolates $(\mathrm{N}=29)$ according to the source of isolation.

\subsection{Antibiotic susceptibility analysis in WHONET 2019.}

By using an updated definition of WHONET 2019 Software, from the zone of inhibition (in $\mathrm{mm}$ ) (Figure 2), sensitivity results were obtained, showing that $63.6 \%$ isolates were possible ESBL (Extended Spectrum Beta-lactamase) producers (Figure 3). Maximum resistance was found against streptogramin class of antibiotic combination - Quinupristin/Dalfopristin (60\%), which is known to be used to treat infection of various enteric bacteria including E. coli and Shigella flexneri along with Staphylococci and Vancomycin-Resistant Enterococcus faecium [15]. Nearly $50 \%$ of isolates were resistant to Cefaperazone (55.2\%), clarithromycin $(53.8 \%)$, ampicillin $(48.3 \%)$, followed by fluoroquinolone (Ciprofloxacin, Levofloxacin), tetracyclines (Doxycycline), and trimethoprim-Sulfamethoxazole (34.5\% each). These antibiotics with veterinary usage approval showed little lower resistance than other studies from India $[16,17$, 18]. However, the presence of carbapenem-resistant from E. coli isolates from bovine mastitis alongside MRSA (Methicillin-Resistant Staphylococcus aureus) is supporting our findings of Carbapenem-resistant E. coli isolates (13.8\%), which is still a higher case than previously reported by Bandyopadhyay et al., 2015 [19]. Colistin was resistant in 9.1\% isolates, with a minimum 3.4\% resistance in aminoglycosides and chloramphenicol. Based on these sensitivity data, the percentages of MDR and possible XDR E. coli isolates were $80 \%(\mathrm{~N}=23)$ and $13 \%$ 
$(\mathrm{N}=4)$, respectively (Figure 4), which is relatively higher for animal data than the findings in earlier studies [20]. A study on pattern analysis in E. coli from domestic and wild fecal samples related to human septage and sewage water showed resistance against tetracycline, cephalothin, and sulfamethoxazole, and streptomycin [21] was common, supporting our research data.

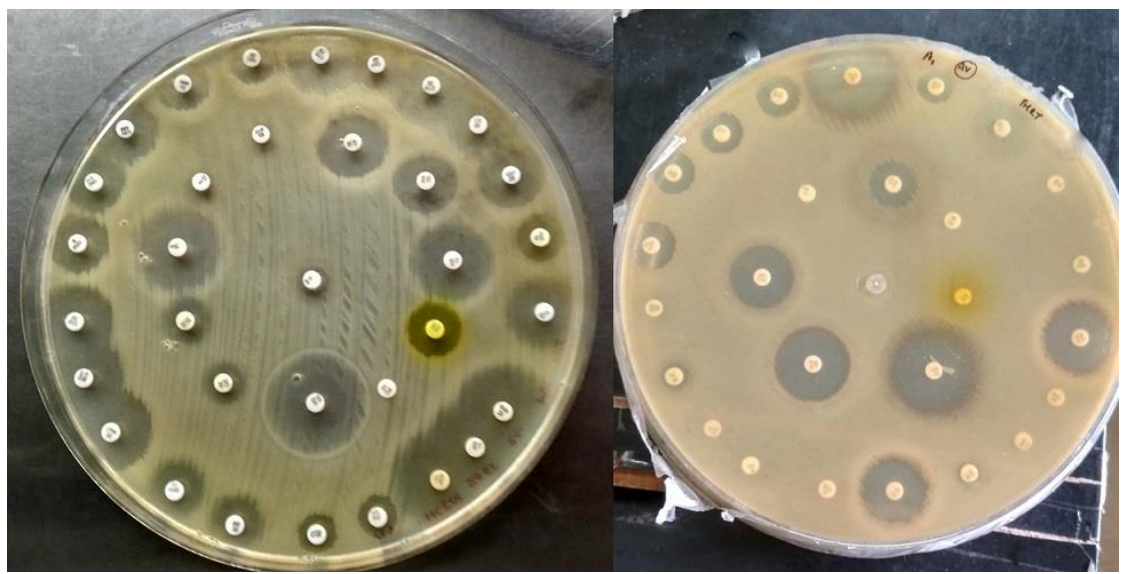

Figure 2. Antibiotic susceptibility results by disk diffusion method in Escherichia coli isolates.

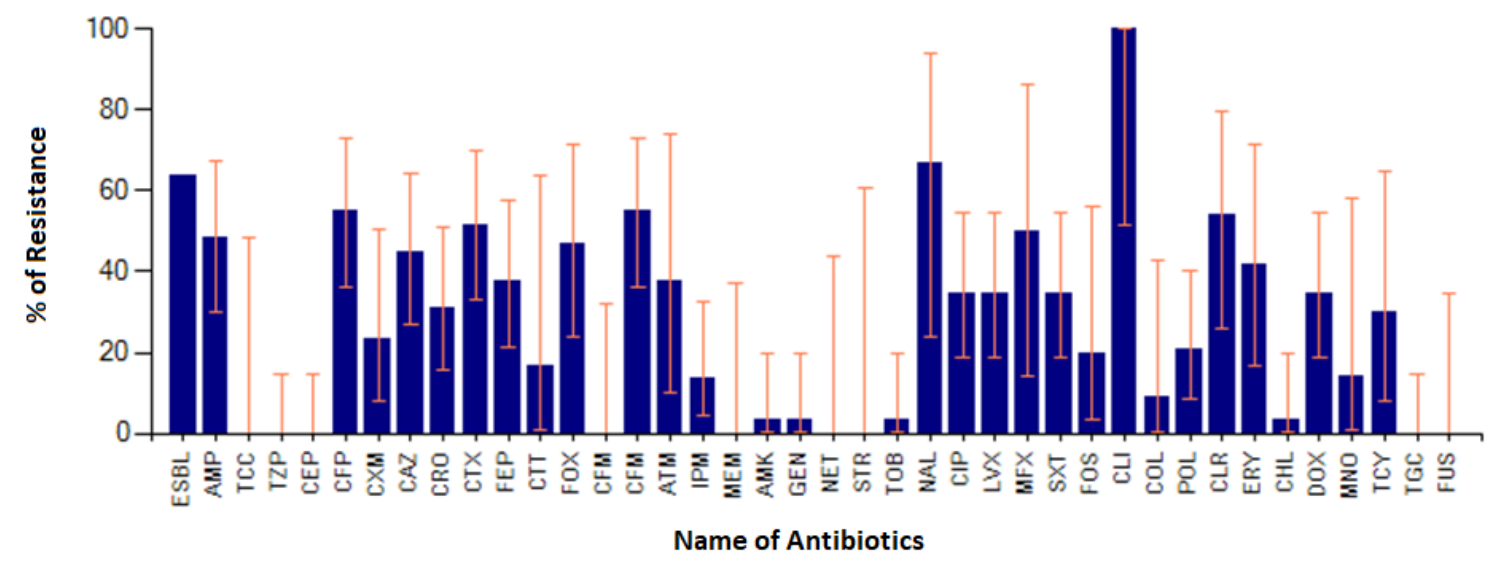

KEY: AMP: Ampicillin, TCC: Ticarcillin-Clavulanic acid, TZP: Piperacillin-Tazobactam, CEP: Cephalothin, CFP: cefpirome, CXM: Cefuroxime, CAZ: Ceftazidime, CRO: Ceftriaxone, CTX: Cefotaxime, FEP: Cefepime, CTT: Cefotetan, FOX: Cefoxitin, CFM: Cefixime, ATM: Aztreonam, IPM: Imipenem, MEM: Meropenem, AMK: Amikacin, GEN: Gentamicin, NET: Netillin/Netilmicin, STR: Streptomycin, TOB: Tobramycin, NAL: Nalidixic acid, CIP: Ciprofloxacin, LVX: Levofloxacin, MFX: Moxifloxacin, SXT: Trimethoprim/Sulfamethoxazole, FOS: Fosfomycin, CLI: Clindamycin, COL: Colistin, POL: Polymyxin B, CLR: Clarithromycin, ERY: Erythromycin, CHL: Chloramphenicol, DOX: Doxycycline, MNO: Minocycline, TCY: Tetracycline, TGC: Tigecycline, FUS: Fusidic acid

Figure 3. Percentage antibiotic resistance in Escherichia coli.

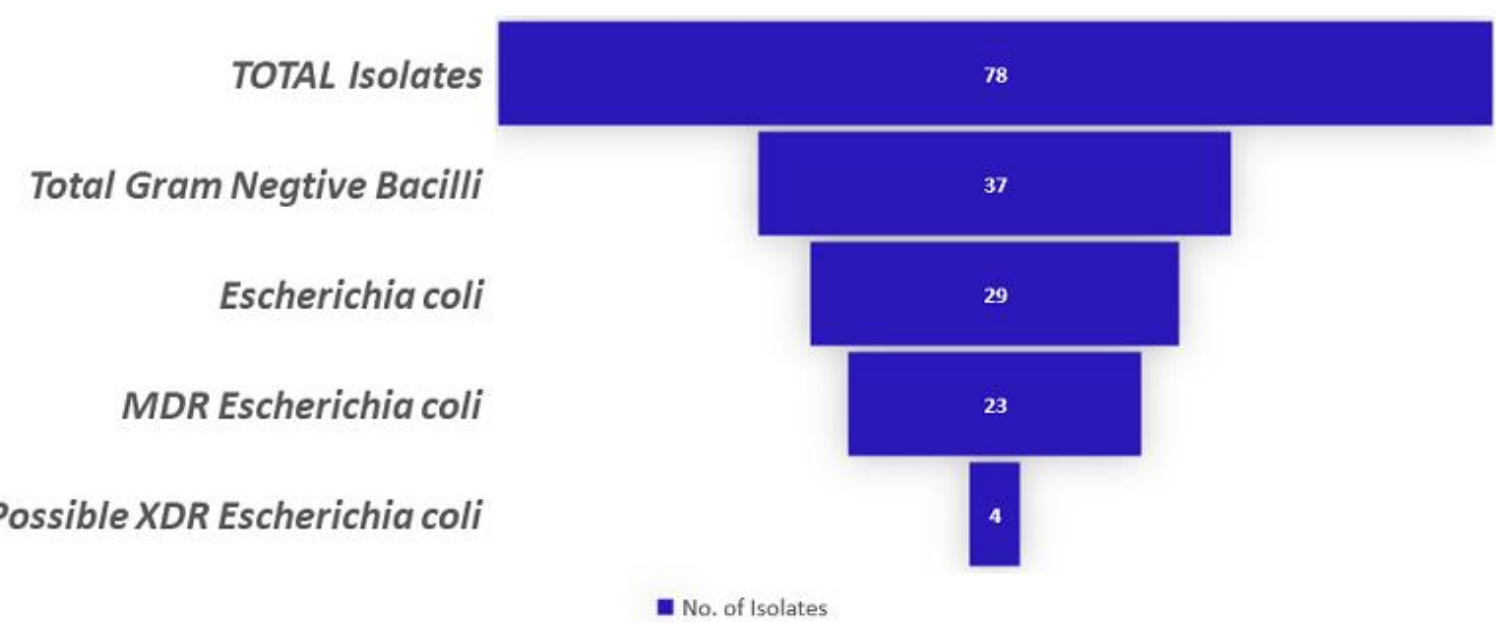

Figure 4. Categorization of Escherichia coli isolates into MDR and possible XDR using WHONET software by following the definition given by Magiorakas et al. [14]. 


\subsection{Retrospective literature analysis (2015-2019).}

Literature available on NCBI PubMed platform was screened for antimicrobial resistance in domestic or wild animals and birds or food sources. Twenty-two research papers (Table 1) were selected satisfying the following inclusion criteria: research papers published between the years 2015 and 2019 with antimicrobial susceptibility records for Escherichia coli either in the form of the zone of inhibition (ZOI) or minimum inhibitory concentration (MIC).

Table 1. Literature studied involving antimicrobial resistance analysis in domestic and wild animals and birds.

\begin{tabular}{|c|c|c|c|}
\hline No & Year & Title & Reference \\
\hline 1 & 2015 & Isolation of Escherichia coli and Salmonella sp. from free-ranging wild animals & [22] \\
\hline 2 & 2015 & $\begin{array}{l}\text { Application of swine manure on agricultural fields contributes to extended-spectrum B-lactamase } \\
\text { producing Escherichia coli spread in Taiwan, China }\end{array}$ & [23] \\
\hline 3 & 2015 & $\begin{array}{l}\text { Prevalence of Extended-Spectrum Cephalosporin - Resistant Escherichia coli in a farrowing farm: } \\
\text { ST1121 clone harbouring IncHI2 plasmid contributes to the dissemination of blaCMY-2 }\end{array}$ & {$[24]$} \\
\hline 4 & 2015 & $\begin{array}{l}\text { Widespread distribution of CTX-M and plasmid-mediated AmpC } \beta \text {-lactamases in Escherichia coli } \\
\text { from Brazilian chicken meat }\end{array}$ & {$[25]$} \\
\hline 5 & 2016 & Emergence of antimicrobial-resistant Escherichia coli of animal origin spreading in humans & [26] \\
\hline 6 & 2016 & $\begin{array}{l}\text { Diversity of Escherichia coli strains involved in vertebral osteomyelitis and arthritis in broilers in } \\
\text { Brazil }\end{array}$ & [27] \\
\hline 7 & 2016 & $\begin{array}{l}\text { Extended-spectrum } \beta \text {-lactamase producing Escherichia coli isolated from wild birds in Saskatoon, } \\
\text { Canada }\end{array}$ & [28] \\
\hline 8 & 2017 & Virulence and transcriptome profile of multidrug-resistant Escherichia coli from chicken & [29] \\
\hline 9 & 2017 & $\begin{array}{l}\text { Probable secondary transmission of antimicrobial-resistant Escherichia coli between people living } \\
\text { with and without pets }\end{array}$ & [30] \\
\hline 10 & 2017 & $\begin{array}{l}\text { Occurrence of Escherichia coli } \mathrm{O} 157: \mathrm{H} 7 \text { in cattle feces and contamination of carcass and various } \\
\text { contact surfaces in abattoir and butcher shops of Hawassa, Ethiopia }\end{array}$ & [31] \\
\hline 11 & 2017 & $\begin{array}{l}\text { Characteristics of Escherichia coli isolated from broiler chickens with colibacillosis in commercial } \\
\text { farms from a common hatchery }\end{array}$ & [32] \\
\hline 12 & 2017 & $\begin{array}{l}\text { Biofilm formation potential of heat-resistant Escherichia coli dairy isolates and the complete genome } \\
\text { of multidrug-resistant, heat-resistant strain FAM21845 }\end{array}$ & [33] \\
\hline 13 & 2017 & $\begin{array}{l}\text { Identification of atypical enteropathogenic Escherichia coli } 098 \text { from golden snub-nosed monkeys } \\
\text { with Diarrhoea in China }\end{array}$ & {$[34]$} \\
\hline 14 & 2017 & $\begin{array}{l}\text { Characterization and zoonotic impact of Shiga toxin-producing Escherichia coli in some wild bird } \\
\text { species }\end{array}$ & [35] \\
\hline 15 & 2017 & $\begin{array}{l}\text { Plasmid-mediated novel blaNDM-17 gene encoding a carbapenemase with enhanced activity in a } \\
\text { sequence type } 48 \text { Escherichia coli Strain }\end{array}$ & [36] \\
\hline 16 & 2017 & Colistin resistance gene mcr-1 and its variant in Escherichia coli isolates from chickens in China & [37] \\
\hline 17 & 2017 & $\begin{array}{l}\text { High prevalence of CTX-M-15-Type ESBL-Producing E. coli from migratory avian species in } \\
\text { Pakistan }\end{array}$ & [38] \\
\hline 18 & 2018 & $\begin{array}{l}\text { Molecular analysis of Shiga toxin-producing Escherichia coli o157:H7 and non-o157 strains isolated } \\
\text { from calves }\end{array}$ & [39] \\
\hline 19 & 2018 & $\begin{array}{l}\text { Antibiotic-resistant Escherichia coli and class-1 integrons in humans, domestic animals, and wild } \\
\text { primates in rural Uganda }\end{array}$ & [40] \\
\hline 20 & 2019 & Comparative genomic analysis of 127 E. coli strains isolated from domestic animals diarrhea in China & [41] \\
\hline 21 & 2019 & $\begin{array}{l}\text { High incidence of multidrug-resistant Escherichia coli co-harbouring mcr-1 and blaCTX-M-15 } \\
\text { recovered from pigs }\end{array}$ & [42] \\
\hline 22 & 2019 & $\begin{array}{l}\text { Virulence gene profiles, antimicrobial resistance, and phylogenetic groups of fecal Escherichia coli } \\
\text { strains isolated from broiler chickens in Algeria }\end{array}$ & [43] \\
\hline
\end{tabular}

These twenty-two research paper includes 724 samples of animal pathogen whose drug susceptibility data were taken into account and antibiotics were categorized under following classes same as used in this same research: aminopenicillin, aminopenicillin + inhibitors, cephalosporins, aminoglycosides, phenicol, tetracyclines, folate inhibitors, monobactam, quinolones, fluoroquinolones, polymyxins, and macrolides. Manual screening for categorizing literature data by following the same definition reported that more than $60 \%$ of isolates were MDR. Additionally, $17.40 \%$ of isolates were resistant to more than six antimicrobial categories with 123 pan-susceptible and 172 isolates resistant to less than two antimicrobial categories (Figure 5). 


\begin{tabular}{|c|c|}
\hline $\begin{array}{c}\text { Categories } \\
\text { Resistant }\end{array}$ & $\begin{array}{c}\text { No. of } \\
\text { Isolates }\end{array}$ \\
\hline $\mathbf{0}$ & 123 \\
\hline $\mathbf{1}$ & 109 \\
\hline $\mathbf{2}$ & 57 \\
\hline $\mathbf{3}$ & 88 \\
\hline $\mathbf{4}$ & 91 \\
\hline $\mathbf{5}$ & 74 \\
\hline $\mathbf{6}$ & 56 \\
\hline $\mathbf{7}$ & 77 \\
\hline $\mathbf{8}$ & 33 \\
\hline $\mathbf{9}$ & 9 \\
\hline $\mathbf{1 0}$ & 7 \\
\hline$>3$ & 347 \\
\hline$>\mathbf{6}$ & $\mathbf{1 2 6}$ \\
\hline$>\mathbf{3}$ & 435 \\
\hline
\end{tabular}

(a)

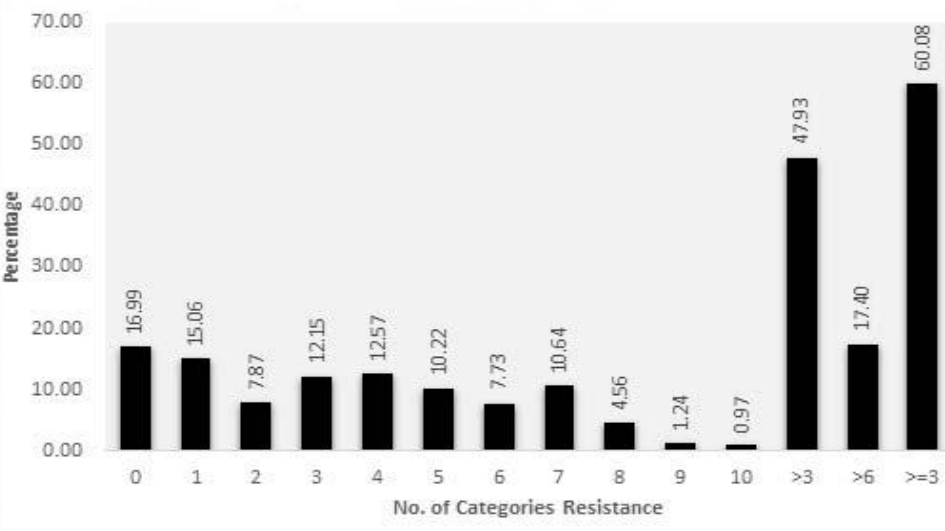

(b)

Figure 5. Drug resistance isolates from literature data: (a) Numbers of isolate resistant to the respective numbers of antibiotic category. Resistance against a maximum of ten categories of antimicrobials was noted out of a total of 724 isolates; 435 isolates were found resistant to more than or equal to 3 categories (MDR), while 126 isolates were resistant to more than six antimicrobial categories. (b) Graphical representation of resistance isolates in percentage.

By considering MDR isolates, there were 164 different resistant patterns found for 429 isolates. Over the five-year period, the percentage resistance in beta-lactam class of antibiotics were found increased tremendously in birds $(12.50 \%-92.65 \%)$, cattle $(4.75 \%-48.15 \%)$, chicken $(37.50 \%$ - $85.19 \%)$, sheep - goat $(2.50 \%$ - $21.82 \%)$ and even swine $(35.71 \%-40.28 \%)$ (Figure 6). Same were the cases with tetracyclines $(9.52 \%-96.97 \%)$ and sulphonamides/folate pathway inhibitors $(9.52 \%-87.88 \%)$ in different species. However, a sharp decrease in tetracycline resistance in swine $(96.97 \%$ - 66.67\%) was reported in 2019. In chicken, aminoglycosides resistance was recorded highest in 2017 (81.74\%), which later on found decreased to $55.88 \%$ (2018). The opposite was the case with the quinolone resistance, which decreased at first from $80.00 \%$ (2016) to $77.39 \%$ (2017), which again increased tremendously to $97.06 \%$ (2018). Polymyxin resistance was $55.65 \%$ and $69.70 \%$ in chicken (2017) and swine (2018), respectively.

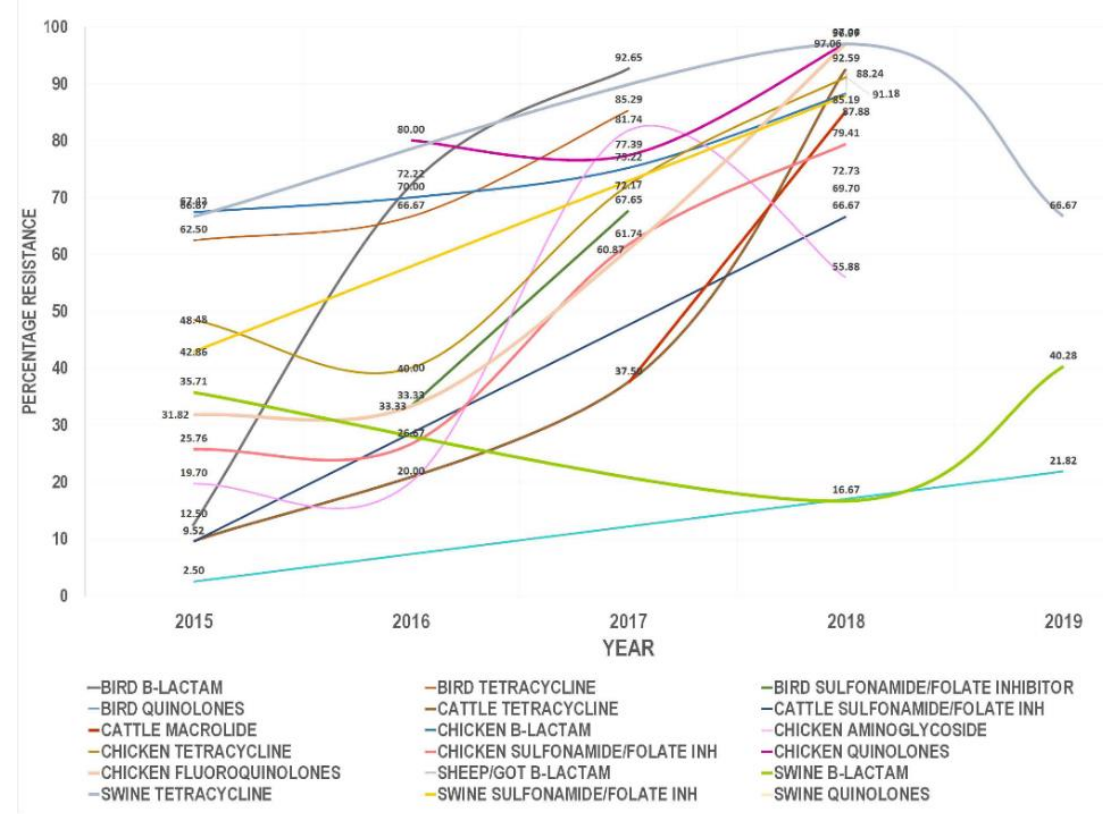

Figure 6. Comparative analysis of antibiotic resistance from different sources - birds, cattle, chicken, and swine based on the five-year (2015-2019) Literature data. 


\section{Conclusions}

Globally, there is a wide usage of antimicrobial agents as growth promoters besides maintaining the livestock's health. Center for Disease Dynamics Economics and Policy (CDDEP) estimated that 131,109 tons of antimicrobial consumption in 2013 globally in livestock would be increased by $52 \%$ by 2030 mainly due to over-usage in the middle-income countries like India to meet the consumer demands [44]. Overuse of these antimicrobial agents contributes to the spread of drug-resistant pathogens from animals to humans. Although E. coli being an innocuous resident of the intestinal tract of warm-blooded animals, including humans, it is well known for causing diarrheal and extra-intestinal diseases. On $9^{\text {th }}$ December 2020, WHO published data showing the top 10 causes of death worldwide responsible for $55 \%$ of total death worldwide. According to WHO neonatal conditions stood first and third, respectively, for lower and lower-middle-income countries in this list. Additionally, it is also a significant part of communicable top disease conditions [45]. Though Group B Streptococci infection is a primary etiological agent, E. coli infection is the major cause of mortality [46]. Several deaths among the children under five years, Diarrheal disease in post-neonates, and sepsis in neonate posse second and third major concern, respectively [47]. As compared to other countries, in India, antibiotic resistance is higher in comparison to their usage. [9]. Additionally, carbapenem and third-generation cephalosporin-resistant E. coli is included in the WHO priority pathogen list 1 (Critical) [48]. Hence, it needs to be addressed. Increasing drug resistance in animals and birds also increases the risk of zoonosis. Previous studies on effects of irrational use or overexploitation of antibiotics at subinhibitory concentrations had provided the basics of induction of biofilm formation in MDR clinical isolates [49] that can be rarely resolved in patients until removal of the colonized surface from the body resulting in increased morbidity and mortality [50]. Thus, understanding the frequency of the antibiotic resistance occurring together can help in deciding antibiotic policies both in human as well as animals as a prerequisite step to develop one health approach in addition to the generating base for future genotypic characterization of isolates to identify the causatives responsible for the spread of resistance genes across human population or animal as host and human interface.

\section{Funding}

This research received no external funding.

\section{Acknowledgments}

I would like to thank Dinesh sir, Tulsidas sir for providing me veterinary samples and their valuable guidance. I am thankful for providing laboratory supports from UGC-SAP-II projects. I would also like to acknowledge Paresh sir, Advance Diagnostic laboratory for automated identification facility.

\section{Conflicts of Interest}

The authors declare no conflict of interest.

\section{References}

1. Singh, S.; Menon, V.P.; Mohamed, Z.U.; Kumar, V.A.; Nampoothiri, V.; Sudhir, S.; Moni, M.; Dipu, T.S.; Dutt, A.; Edathadathil, F.; Keerthivasan, G.; Kaye, K.S.; Patel, P.K. Implementation and Impact of an 
Antimicrobial Stewardship Program at a Tertiary Care Center in South India. Open Forum Infect. Dis. 2019, 6, 1-7, https://doi.org/10.1093/ofid/ofy290.

2. Milton, A.A.P.; Agarwal, R.K.; Priya, G.B.; Aravind, M.; Athira, C.K.; Rose, L.; Swaminathan, M.; Sharma, A.K.; Kumar, A. Captive Wildlife from India as Carriers of Shiga Toxin-Producing, Enteropathogenic and Enterotoxigenic Escherichia Coli. J. Vet. Med. Sci. 2018, 81, 321-327, https://doi.org/10.1292/jvms.180488 .

3. Bortolami, A.; Zendri, F.; Maciuca, E. I.; Wattret, A.; Ellis, C.; Schmidt, V.; Pinchbeck, G.; Timofte, D. Diversity, Virulence, and Clinical Significance of Extended-Spectrum $\beta$-Lactamase- and PAmpC-Producing Escherichia Coli From Companion Animals. Front. Microbiol. 2019, 10, 1-15, https://doi.org/10.3389/fmicb.2019.01260.

4. Bezborodova, N.; Sokolova, O.; Ryaposova, M.; Isakova, M. Genetic Markers of Antibiotic Resistance of Pathogenic Bacteria in the Milk of Cows and Goats. ISPC 2019, 167, 44-48, https://doi.org/10.2991/ispc19.2019.11.

5. $\quad$ Bhave, S.; Kolhe, R.; Mahadevaswamy, R.; Bhong, C.; Jadhav, S.; Nalband, S.; Gandhale, D.; Muglikar, D. Phylogrouping and Antimicrobial Resistance Analysis of Extraintestinal Pathogenic Escherichia Coli Isolated from Poultry Species. Turkish J. Vet. Anim. Sci. 2019, 43, 117-126, https://doi.org/10.3906/vet1808-47.

6. Krivonogova, A.; Isaeva, A.; Loretts, O.; Chentsova, A. Composition and Antibiotic Susceptibility of Opportunistic Pathogenic Microflora in Poultry Farms Aimed at Egg or Meat Farming. ISPC 2019, 167, 542-545, https://doi.org/10.2991/ispc-19.2019.121.

7. $\quad$ Ludden, C.; Raven, K. E.; Jamrozy, D.; Gouliouris, T.; Blane, B.; Coll, F. Demonstrates Distinct Lineages and Mobile Genetic Elements 2019; pp. 1-12.

8. Boyle, S.F.; Corrigan, V.K.; Buechner-Maxwell, V.; Pierce, B.J. Evaluation of Risk of Zoonotic Pathogen Transmission in a University-Based Animal Assisted Intervention (AAI) Program. Front. Vet. Sci. 2019, 6, 1-10, https://doi.org/10.3389/fvets.2019.00167.

9. Klein, E.Y.; Tseng, K. K.; Pant, S.; Laxminarayan, R. Tracking Global Trends in the Effectiveness of Antibiotic Therapy Using the Drug Resistance Index. BMJ Glob. Heal. 2019, 4, 1-7, https://doi.org/10.1136/bmjgh-2018-001315.

10. Clinical and Laboratory Standards Institute (CLSI). Performance Standards for Antimicrobial Disk and Dilution Susceptibility Tests for Bacteria Isolated from Animals; Approved Standard http://clsivet.org/Login.aspx (accessed Dec 10, 2019).

11. Stoica, C.; Sorescu, I. ABIS online - Advanced Bacterial Identification Software, an original tool for phenotypic bacterial identification. www.tgw1916.net (accessed Nov 14, 2019).

12. Hudzicki, J. Kirby-Bauer Disk Diffusion Susceptibility Test Protocol. 2016, No. December 2009, 1-23.

13. Stelling, J.M.; O'Brien, T.F. Surveillance of Antimicrobial Resistance: The WHONET Program. Clinical Infectious Diseases 1997, 24, S157-S168, https://doi.org/10.1093/clinids/24.supplement_1.s157.

14. Magiorakos, A.P.; Srinivasan, A.; Carey, R.B.; Carmeli, Y.; Falagas, M.E.; Giske, C.G.; Harbarth, S.; Hindler, J.F.; Kahlmeter, G.; Olsson-Liljequist, B.; Paterson, D.L.; Rice, L.B.; Stelling, J.; Struelens, M.J.; Vatopoulos, A.; Weber, J.T.; Monnet, D.L. Multidrug-Resistant, Extensively Drug-Resistant and PandrugResistant Bacteria: An International Expert Proposal for Interim Standard Definitions for Acquired Resistance. Clin. Microbiol. Infect. 2012, 18, 268-281, https://doi.org/10.1111/j.1469-0691.2011.03570.x.

15. Wishart, D.S.; Feunang, Y.D.; Guo, A.C.; Lo, E.J.; Marcu, A.; Grant, J.R.; Sajed, T.; Johnson, D.; Li, C.; Sayeeda, Z.; Assempour, N.; Iynkkaran, I.; Liu, Y.; MacIejewski, A.; Gale, N.; Wilson, A.; Chin, L.; Cummings, R.; Le, Di.; Pon, A.; Knox, C.; Wilson, M. DrugBank 5.0: A Major Update to the DrugBank Database for 2018. Nucleic Acids Res. 2018, 46, D1074-D1082, https://doi.org/10.1093/nar/gkx1037.

16. Kar, D.; Bandyopadhyay, S.; Bhattacharyya, D.; Samanta, I.; Mahanti, A.; Nanda, P.K.; Mondal, B.; Dandapat, P.; Das, A.K.; Dutta, T.K.; Bandyopadhyay, S.; Singh, R.K. Molecular and Phylogenetic Characterization of Multidrug-Resistant Extended-Spectrum Beta-Lactamase Producing Escherichia Coli Isolated from Poultry and Cattle in Odisha, India. Infect. Genet. Evol. 2015, 29, 82-90, https://doi.org/10.1016/j.meegid.2014.11.003.

17. Preethirani, P.L.; Isloor, S.; Sundareshan, S.; Nuthanalakshmi, V.; Deepthikiran, K.; Sinha, A.Y.; Rathnamma, D.; Prabhu, K.N.; Sharada, R.; Mukkur, T.K.; Hegde, N.R. Isolation, Biochemical and Molecular Identification, and in-Vitro Antimicrobial Resistance Patterns of Bacteria Isolated from Bubaline Subclinical Mastitis in South India. PLoS One 2015, 10, https://doi.org/10.1371/journal.pone.0142717.

18. Arya, G.; Roy, A.; Choudhary, V.; Yadav, M.M.; Joshi, C.G. Serogroups, Atypical Biochemical Characters, Colicinogeny and Antibiotic Resistance Pattern of Shiga Toxin-Producing Escherichia Coli Isolated from Diarrhoeic Calves in Gujarat, India. Zoonoses Public Health 2008, 55, 89-98.

19. Bandyopadhyay, S.; Samanta, I.; Bhattacharyya, D.; Nanda, P.K.; Kar, D.; Chowdhury, J.; Dandapat, P.; Das, A.K.; Batul, N.; Mondal, B.; Dutta, T.K.; Das, G.; Das, B.C.; Naskar, S.; Bandyopadhyay, U.K.; Das, S.C.; Bandyopadhyay, S. Co-Infection of Methicillin-Resistant Staphylococcus Epidermidis, MethicillinResistant Staphylococcus Aureus and Extended-Spectrum $\beta$-Lactamase Producing Escherichia Coli in Bovine Mastitis - Three Cases Reported from India. Vet. Q. 2015, 35, 56-61, https://doi.org/10.1080/01652176.2014.984365. 
20. Sahoo, K.C.; Tamhankar, A.J.; Sahoo, S.; Sahu, P.S.; Klintz, S.R.; Lundborg, C.S. Geographical Variation in Antibiotic-Resistant Escherichia Coli Isolates from Stool, Cow-Dung and Drinking Water. Int. J. Environ. Res. Public Health 2012, 9, 746-759, https://doi.org/10.3390/ijerph9030746.

21. Sayah, R. S.; Kaneene, J. B.; Johnson, Y.; Septage, H.; Water, S.; Miller, R. Patterns of Antimicrobial Resistance Observed in Escherichia Coli Isolates Obtained from Domestic- and Wild-Animal Fecal Samples, Human Septage, and Patterns of Antimicrobial Resistance Observed in Escherichia Coli Isolates Obtained from Domestic- and W. Appl. Environ. Microbiol. 2005, 71, 1394-1404, https://doi.org/10.1128/aem.71.3.1394-1404.2005.

22. Iovine, R.de O.; Dejuste, C.; Miranda, F.; Filoni, C.; Bueno, M.G.; de Carvalho, V.M. Isolation of Escherichia Coli and Salmonella Spp. from Free-Ranging Wild Animals. Brazilian J. Microbiol. 2015, 46, 1257-1263, https://doi.org/10.1590/S1517-838246420140843.

23. Gao, L.L.; Tan, Y.; Zhang, X.D.; Hu, J.Q.; Miao, Z.M.; Wei, L.M.; Chai, T.J. Emissions of Escherichia Coli Carrying Extended-Spectrum $\beta$-Lactamase Resistance from Pig Farms to the Surrounding Environment. Int. J. Environ. Res. Public Health 2015, 12, 4203-4213, https://doi.org/10.3390/ijerph120404203.

24. Deng, H.; Si, H.Bin; Zeng, S.Y.; Sun, J.; Fang, L.X.; Yang, R.S.; Liu, Y.H.; Liao, X.P. Prevalence of Extended-Spectrum Cephalosporin-Resistant Escherichia Coli in a Farrowing Farm: ST1121 Clone Harboring IncHI2 Plasmid Contributes to the Dissemination of BlaCMY-2. Front. Microbiol. 2015, 6, https://doi.org/10.3389/fmicb.2015.01210.

25. Alvarenga, L.; Botelho, B.; Kraychete, G.B.; Lapa, J.; Viller, D.; Regis, V.; Picão, R.C.; Moreira, B.M.; Bonelli, R.R. Widespread Distribution of CTX-M and Plasmid-Mediated AmpC $\beta$-Lactamases in Escherichia Coli from Brazilian Chicken Meat. 2015, 110, 249-254, https://doi.org/10.1590/007402760140389.

26. Skurnik, D.; Clermont, O.; Guillard, T.; Launay, A.; Danilchanka, O.; Diancourt, L.; Kadlec, K.; Roux, D.; Jiang, D.; Dion, S.; Aschard, H.; Denamur, M.; Cywes-bentley, C.; Schwarz, S.; Tenaillon, O.; Andremont, A.; Picard, B.; Mekalanos, J.; Brisse, S.; Denamur, E. Emergence of Antimicrobial-Resistant Escherichia Coli of Animal Origin Spreading in Humans. Molecular Biology and Evolution 2015, 33, 898-914, https://doi.org/10.1093/molbev/msv280.

27. Fortes, J.; Braga, V.; Chanteloup, N. K.; Trotereau, A.; Baucheron, S.; Guabiraba, R.; Ecco, R.; Schouler, C. Diversity of Escherichia Coli Strains Involved in Vertebral Osteomyelitis and Arthritis in Broilers in Brazil. BMC Veterinary Research 2016, 12, 1-12, https://doi.org/10.1186/s12917-016-0762-0.

28. Parker, D.; Sniatynski, M.K.; Mandrusiak, D.; Rubin, J.E. Extended-Spectrum $\beta$-Lactamase Producing Escherichia Coli Isolated from Wild Birds in Saskatoon, Canada. Lett. Appl. Microbiol. 2016, 63, 11-15, https://doi.org/10.1111/lam.12589.

29. Hussain, H.I.; Iqbal, Z.; Seleem, M.N.; Huang, D.; Sattar, A.; Hao, H.; Yuan, Z. Virulence and Transcriptome Profile of Multidrug-Resistant Escherichia Coli from Chicken. Sci. Rep. 2017, 7, https://doi.org/10.1038/s41598-017-07798-1.

30. Chung, Y.S.; Park, Y.K.; Park, Y.H.; Park, K.T. Probable Secondary Transmission of between People Living with and without Pets. Journal of Veterinary Medical Science 2017, 79, 486-491, https://doi.org/10.1292/jvms.16-0585.

31. Atnafie, B.; Paulos, D.; Abera, M.; Tefera, G.; Hailu, D.; Kasaye, S. Occurrence of Escherichia Coli O157 : H7 in Cattle Feces and Contamination of Carcass and Various Contact Surfaces in Abattoir and Butcher Shops of Hawassa, Ethiopia. BMC Microbiol. 2017, 17, 1-7, https://doi.org/10.1186/s12866-017-0938-1.

32. Ozaki, H.; Matsuoka, Y.; Nakagawa, E.; Murase, T. Characteristics of Escherichia Coli Isolated from Broiler Chickens with Colibacillosis in Commercial Farms from a Common Hatchery. Poult. Sci. 2017, 96, 37173724, https://doi.org/10.3382/ps/pex167.

33. Marti, R.; Schmid, M.; Kulli, S.; Schneeberger, K.; Naskova, J.; Knøchel, S.; Ahrens, C.H.; Hummerjohann, J. Biofilm Formation Potential of Heat-Resistant Escherichia Coli Dairy Isolates and the Complete Genome of Multidrug-Resistant, Heat-Resistant Strain FAM21845. Appl. Environ. Microbiol. 2017, 83, https://doi.org/10.1128/AEM.00628-17.

34. Qi, M.; Wang, Q.; Tong, S.; Zhao, G.; Hu, C.; Chen, Y.; Li, X.; Yang, W.; Zhao, Y.; Platto, S.; Duncan, R. I.; Chen, J.; Chen, H.; Guo, A. Identification of Atypical Enteropathogenic Escherichia Coli O98 from Golden Snub-Nosed Monkeys with Diarrhea in China. Front. Vet. Sci. 2017, 4, https://doi.org/10.3389/fvets.2017.00217.

35. Fadel, H.M.; Afifi, R.; Al-Qabili, D.M. Characterization and Zoonotic Impact of Shiga Toxin-Producing Escherichia Coli in Some Wild Bird Species. Vet. World 2017, 10, 1118-1128., https://doi.org/10.14202/vetworld.2017.1118-1128.

36. Liu, Z.; Wang, Y.; Walsh, T.R.; Liu, D.; Shen, Z.; Zhang, R.; Yin, W.; Yao, H.; Li, J.; Shen, J. PlasmidMediated Novel BlaNDM-17 Gene Encoding a Carbapenemase with Enhanced Activity in a Sequence Type 48 Escherichia Coli Strain. Antimicrob. Agents Chemother. 2017, 61, https://doi.org/10.1128/AAC.0223316.

37. Yang, Y.Q.; Li, Y.X.; Song, T.; Yang, Y.X.; Jiang, W.; Zhang, A.Y.; Guo, X.Y.; Liu, B.H.; Wang, Y.X.; Lei, C.W.; Xiang, R.; Wang, H.N. Colistin Resistance Gene Mcr-1 and Its Variant in Escherichia Coli 
Isolates from Chickens in China. Antimicrob. Agents Chemother. 2017, 61, https://doi.org/10.1128/AAC.01204-16.

38. Mohsin, M.; Raza, S.; Schaufler, K.; Roschanski, N.; Sarwar, F.; Semmler, T.; Schierack, P.; Guenther, S. High Prevalence of CTX-M-15-Type ESBL-Producing E. Coli from Migratory Avian Species in Pakistan. Front. Microbiol. 2017, 8, https://doi.org/10.3389/fmicb.2017.02476.

39. Kohansal, M.; Ghanbari Asad, A. Molecular analysis of Shiga toxin-producing Escherichia coli O157:H7 and non-O157 strains isolated from calves. Onderstepoort $J$ Vet Res 2018, 85, e1-e7, https://doi.org/10.4102/ojvr.v85i1.1621.

40. Weiss, D.; Wallace, R.M.; Rwego, I.B.; Gillespie, T.R.; Chapman, C.A.; Singer, R.S.; Goldberg, T.L. Antibiotic-Resistant Escherichia Coli and Class 1 Integrons in Humans, Domestic Animals, and Wild Primates in Rural Uganda. Appl. Environ. Microbiol. 2018, 84, https://doi.org/10.1128/AEM.01632-18.

41. Tang, F.; Wang, J.; Li, D.; Gao, S.; Ren, J.; Ma, L.; Liu, F.; Zhuge, X.; Yan, G.; Lu, Y.; Dai, J. Comparative Genomic Analysis of 127 Escherichia Coli Strains Isolated from Domestic Animals with Diarrhea in China. BMC Genomics 2019, 20, https://doi.org/10.1186/s12864-019-5588-2.

42. Shafiq, M.; Huang, J.; Ur Rahman, S.; Shah, J. M.; Chen, L.; Gao, Y.; Wang, M.; Wang, L. High Incidence of Multidrug-Resistant Escherichia Coli Coharboring Mcr-1 and BlaCTX-M-15 Recovered from Pigs. Infect. Drug Resist. 2019, 12, 2135-2149. https://doi.org/10.2147/IDR.S209473.

43. Messaili, C.; Messai, Y.; Bakour, R. Virulence Gene Profiles, Antimicrobial Resistance and Phylogenetic Groups of Fecal Escherichia Coli Strains Isolated from Broiler Chickens in Algeria. Vet. Ital. 2019, 55, 3546, https://doi.org/10.12834/VetIt.799.3865.2.

44. Van Boeckel, T.P.; Brower, C.; Gilbert, M.; Grenfell, B.T.; Levin, S.A.; Robinson, T.P.; Teillant, A.; Laxminarayan, R. Global Trends in Antimicrobial Use in Food Animals. Proc. Natl. Acad. Sci. U. S. A. 2015, 112, 5649-5654, https://doi.org/10.1073/pnas.1503141112.

45. World Health Organization. The top 10 causes of death https://www.who.int/news-room/factsheets/detail/the-top-10-causes-of-death (accessed Dec 12, 2020).

46. Simonsen, K.A.; Anderson-Berry, A.L.; Delair, S.F.; Dele Davies, H. Early-Onset Neonatal Sepsis. Clin. Microbiol. Rev. 2014, 27, 21-47, https://doi.org/10.1128/CMR.00031-13.

47. World Health Organization. Causes of Child Mortality, 2015. Glob. Heal. Estim. Tech. Pap. 2015.

48. Who Publishes List of Bacteria for Which New Antibiotics Are Urgently Needed https://www.who.int/newsroom/detail/27-02-2017-who-publishes-list-of-bacteria-for-which-new-antibiotics-are-urgently-needed (accessed Nov 16, 2019).

49. Nucleo, E.; Steffanoni, L.; Fugazza, G.; Migliavacca, R.; Giacobone, E.; Navarra, A.; Pagani, L.; Landini, P. Growth in Glucose-Based Medium and Exposure to Subinhibitory Concentrations of Imipenem Induce Biofilm Formation in a Multidrug-Resistant Clinical Isolate of Acinetobacter Baumannii. BMC Microbiol. 2009, 9, https://doi.org/10.1186/1471-2180-9-270.

50. Cos, P.; Tote, K.; Horemans, T.; Maes, L. Biofilms: An Extra Hurdle for Effective Antimicrobial Therapy. Curr. Pharm. Des. 2010, 16, 2279-2295, https://doi.org/10.2174/138161210791792868. 